\title{
Dinamika Kebijakan Pemerintah Pembatasan Sosial Berskala Besar Dalam Penanganan Covid-19 Di Kota Tarakan
}

\author{
Nurul Rahmi Aulia', Nuryanti Mustari'2, Nursaleh Hartaman ${ }^{3}$ \\ 1,2,3Program Studi Ilmu Pemerintahan Universitas Muhammadiyah Makassar \\ Email: nurulrahmiaulia59@gmail.com
}

\begin{abstract}
Abstrak: Upaya pemerintah Kota Wilayah Tarakan dalam kewaspadaan terhadap virus covid-19 ini mengeluarkan peraturan walikota yang sebelumnya telah disetujui oleh Kementrian Kesehatan yang tertuang dalam UU NO.17 tahun 2020 tentang Pembatasan Sosial Berskala Besar (PSBB). Adanya pro dan kontra dimasyarakat terkait pelaksanaan PSBB ini menimbulkan berbagai dinamika. Penulis menemukan permasalahan dalam penelitian ini, yaitu bagaimana dinamika kebijakan yang dihadapi pemerintah kota Tarakan pada penerapan (PSBB) penanganan covid-19 untuk menekan angka penularan covid-19 di Kota Tarakan. Pemerintah Kota Tarakan telah melakukan Evaluasi dan pemantauan terhadap efektifitas pelaksanaan PSBB. Penelitian yang digunakan adalah kualitatif dengan menggunakan metode penelitian secara daring, dan dengan menggunakan data sekunder sebagai analisis utama penelitian. Hasil Penelitian menujukkan bahwa Selama Pelaksanaan PSBB Pemerintah Kota Tarakan telah melakukan evaluasi di masyarakat dan ditemukan beberapa aturan yang dikeluarkan belum berjalan dengan tertib salah satunya yang paling banyak ditemukan pelanggaran pada akses laut (baik itu masyarakat, ASN, bahkan anggota dewan). Penerapan 3M juga belum berjalan dengan efektif karena masih banyaknya masyarakat yang kurang kesadaran untuk menggunakan masker pada saat diluar rumah. Berbagai dinamika yang terjadi, Pemkot Tarakan sebisa mungkin mencari solusi yang tanggap terhadap permasalahan seperti yang terjadi pada pengiriman swab dari Kabupaten Nunukan ke Surabaya yang harus melalui Kota Tarakan.
\end{abstract}

\section{Kata Kunci : Dinamika Kebijakan, PSBB, Evaluasi}

Abstract: The efforts of the City Government of the Tarakan Region to be aware of the Covid-19 virus issued a mayoral regulation which was previously approved by the Ministry of Health as stipulated in Law Number 17 Year 2020 About Pembatasan Sosial Berskala Besar (PSBB). The existence of pros and cons in the community regarding the implementation of this PSBB creates various dynamics. The author found a problem in this study, namely how the policy dynamics faced by the government of Tarakan in the implementation (PSBB) of handling covid-19 to reduce the number of covid-19 transmission in Tarakan City. The City Government of Tarakan has evaluated and monitored the effectiveness of the implementation of the PSBB. The research used is qualitative by using online research methods, and by using secondary data as the main analysis of the study. The results showed that during the implementation of the PSBB, the City Government of Tarakan had conducted evaluations in the community and it was found that several regulations issued had not been running in an orderly manner, one of which was the most frequent violations of sea access (also as community, Civil Servant and Senator). The implementation of $3 \mathrm{M}$ has also not been effective because there are still many people who are less aware of using masks when outside the home. The various dynamics that occur, the City Government of Tarakan as much as possible seeks a solution that is responsive to problems such as what happened in the delivery of swabs from Nunukan Regency to Surabaya which must go through Tarakan City.

Keywords: Policy Dynamics, PSBB, Evaluation 


\section{Pendahuluan}

James E Anderson sebagaimana dikutip Islamy (2009) mengungkapkan bahwa kebijakan adalah "a purposive course of action followed by an actor or set of actors in dealing with a problem or matter of concern" (Serangkaian tindakan yang mempunyai tujuan tertentu yang diikuti dan dilaksanakan oleh seorang pelaku atau sekelompok pelaku guna memecahkan suatu masalah tertentu). Carl J Federick sebagaimana dikutip Agustino (2008) mendefinisikan kebijakan sebagai serangkaian tindakan/kegiatan yang diusulkan seseorang, kelompok atau pemerintah dalam suatu lingkungan tertentu dimana terdapat hambatan-hambatan (kesulitan-kesulitan) dan kesempatankesempatan terhadap pelaksanaan usulan kebijaksanaan tersebut dalam rangka mencapai tujuan tertentu. Kebijakan publik merupakan kewenangan pemerintah menjalankan tugas dan fungsinya dalam hubungannya dengan masyarakat dan dunia usaha (Ramdhani \& Ramdhani, 2017). Pada dasarnya kebijakan pemerintah dalam menata kehidupan masyarakat di berbagai aspek merupakan kebijakan yang berorientasi pada kepentingan publik (Dian Herdiana, 2018; Dutta, 2020; Tahir \& Harakan, 2017). Pengertian kebijakan adalah prinsip atau cara bertindak yang dipilih untuk mengarahkan pemilihan keputusan. Dalam setiap penyusunankebijakan publik diawali oleh perumusan masalah yang telah diidentifikasi bahwa kebijakan tersebut ditujukan untuk mengatasi masalah yang terjadi dalam masyarakat (Mustari, 2015).

Covid-19 merupakan penyakit menular yang mulai berkembang di tahun 2019 yang sampai saat ini menjadi permasalahan utama di seluruh dunia. Awal keberadaannya yaitu berasal dari Wuhan, Tiongkok yang diperkirakan berasal dari salah satu hewan liar yaitu kelalawar. Dampak dari terkenanya Covid-19 bagi individu yang terinfeksi yaitu akan mengalami gangguan pernafasan ringan hingga dapat menyebabkan kematian. Sebagai salah satu Negara yang terdampak Negara Kesatuan Republik Indonesia langsung bergerak cepat untuk memutus rantai penyebaran Covid19,mulai dari himbauan pemerintah untuk jaga jarak (Physical distancing) sampai saat ini mengeluarkan kebijakan yaitu Pembatasan Sosial Berskala Besar (PSBB). Untuk mengatasi wabah Covid-19 ini pemerintah pusat memberikan wewenang kepada Pemerintah Daerah Untuk melaksanakan Pembatasan sosial berskala besar (PSBB). Pemerintah daerah yang mengajukan penerapan PSBB kepada Menteri Kesehatan. Hal itu dilandasi oleh peraturan pemerintah yang baru dikeluarkan tahun 2020 yang tertuang dalam Peraturan Pemerintah (PP) Nomor 21 Tahun 2020 tentang PSBB dalam Rangka Percepatan Penanganan Covid-19.

Kebijakan Terhadap Penanganan Pandemi Covid-19 Di Indonesia dianggap belum dapat dilaksanakan dengan baik sebagaimana yang diamanatkan dalam peraturan perundang-undangan, karena masih banyak masyarakat yang melanggar dalam kegiatan PSBB (Saraswati, 2020). Kebijakan Pembatasan Sosial Berskala Besar dengan adanya Pandemi Covid 19 mempunyai dampak yang cukup besar terhadap kehidupan sosial, sehingga menimbulkan dinamika dalam pengambilan keputusan. Dampak dari PSBB yang berlaku, terutama berkaitan dengan kondisi perekonomian saat ini yang merosot 
drastis harus dapat menjamin dan memastikan terutama kepada kaum menengah ke bawah mampu memenuhi kebutuhannya. Sebagai bentuk pemenuhan kebutuhan masyarakat tersebut, kewajiban negara menjamin hak atas hidup masyarakatnya dan tidak terkurangi suatu apapun harkat martabat masyarakatnya. Tidak hanya peran pemerintah saja dalam penanganan kasus Covid-19 ini, namun peran publik dalam hal saling menjaga, saling mengingatkan, dan saling membantu satu sama lain apalagi dikarenakan dampak dari PSBB dalam rangka pencegahan Covid-19 ini dapat menekan dampak negatif terutama dari diterapkannya kebijakan PSBB (Ristyawati, 2020).

Adapun tahapan mekanisme yang harus dipenuhi adalah saat daerah ingin memberlakukan kebijakan PSBB, gubernur, bupati atau wali kota mengusulkan kepada Menteri Kesehatan. Kemudian, Menkes akan menanggapi usulan daerah terkait penerapan PSBB. Dalam menanggapi usulan dari daerah, Menkes meminta pertimbangan Ketua Gugus Tugas Percepatan Penanganan Covid- 19, apakah PSBB dapat diberlakukan di daerah tersebut atau tidak. Pihak lain yang bisa mengajukan PSBB adalah Ketua Gugus Tugas. Ketua dapat mengusulkan kepada Menkes untuk menerapkan PSBB di wilayah tertentu. Daerah tersebut pun harus menerapkan PSBB bila usulan Ketua Gugus Tugas disetujui Menkes.

Salah satu daerah yang terdampak Covid-19 adalah Kota Tarakan yang merupakan salah satu Kota yang berada di Provinsi Kalimantan Utara dan menjadi fokus utama dengan penambahan kasus terbesar sejauh ini. Terlebih Tarakan memiliki angka kasus aktif tertinggi, tanpa mengabaikan tiga kabupaten lainnya. Tarakan adalah kota transit, dan Tarakan sebagai kota dengan roda perekonomian cukup pesat. Sampai saat ini per tanggal 30 November 2020 terkonfirmasi 801 total kasus dan 341 terkonfirmasi aktif atau dinyatakan positif dan sedang melakukan isolasi (tarakankota.go.id). Selain masyarakat petugas di RSUD Tarakan yang terpapar covid-19 per 7 Januari 2021 semakin meningkat. Dengan rincian, dokter spesialis sebanyak enam orang, dokter umum/gigi sebanyak 15 orang, kefarmasian sebanyak 67 orang, perawat/bidan sebanyak 77 orang, tenaga kesehatan (nakes) sebanyak 11 orang dan non-nakes sebanyak 34 orang. 


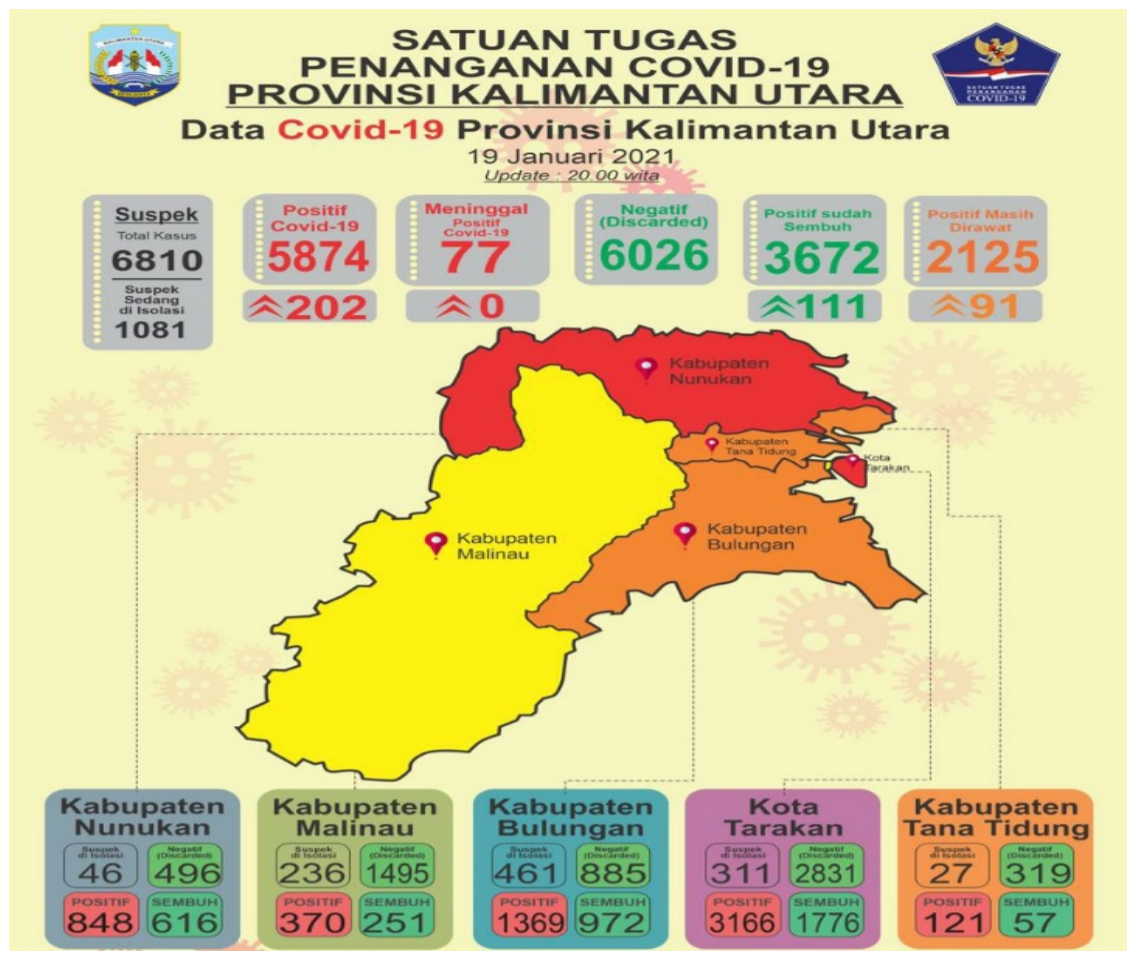

Gambar 1. Data Covid 19 Prov. Kalimantan Utara

Sumber: Data Satgas Covid-19 Prov. Kalimantan Utara

Dari gambar diatas menyatakan bahwa Kota Tarakan menjadi kota dengan jumlah kasus terpapar terbanyak diantara beberapa Kabupaten/Kota yang ada di Kalimantan Utara. Karena itulah Langkah yang di tempuh pemerintah Kota Tarakan untuk memutus mata rantai penyebaran Covid-19 adalah dengan mengajukan PSBB kepada pemerintah Pusat. Langkah ini di ambil mengingat jumlah pasien positif corona terus bertambah. Adanya pro dan kontra yang muncul dimasyarakat terkait pelaksanaan PSBB ini menimbulkan berbagai dinamika. Berdasarkan latar belakang penulis menghasilkan permasalahan dalam penelitian ini, yaitu bagaimana dinamika kebijakan yang dihadapi pemerintah kota Tarakan pada penerapan (PSBB) penanganan covid-19 untuk menekan angka penularan covid-19 di Kota Tarakan. Artikel ini memberikan informasi mengenai hambatan-hambatan selama pelaksanaan PSBB di Kota Tarakan, memberikan gambaran secara umum bagaimana respond dan tanggap masyarakat terhadap kebijakan yang dikeluarkan Pemerintah Kota Tarakan.

\section{Metode Penelitian}

Jenis penelitian ini penelitian kualitatif dengan menggunakan metode penelitian secara daring, Moleong (2010) mengemukakan bahwa penelitian kualitatif adalah prosedur penelitian yang menghasilkan data deskriptif berupa kata-kata tertulis atau lisan dari orang-orang dan prilaku yang dapat diamati. Dengan menggunakan data sekunder sebagai analisis utama penelitian. Sementara itu, (Johnston, 2014) mengemukakan bahwa analisis data sekunder merupakan teknik penelitian yang jarang 
dilakukan digunakan dalam berbagai bidang, meskipun demikian teknik ini dikenal sebagai metode penelitian yang sistematis.

\section{Hasil Dan Pembahasan}

Dinamika kebijakan pada level pemerintahan Kota akan selalu berubah sesuai dengan kepentingan politik, peristiwa dan fenomena yang terjadi serta mengikuti perkembangan zaman sesuai dengan kebutuhan masyarakat. Respons pemerintah yang lamban sejalan dengan konsep agenda setting yang menjelaskan bahwa suatu isu dapat menjadi agenda kebijakan pemerintah ketika terdapat suatu peluang. Sampai saat ini yang menjadi problem adalah Pemerintah masih berfokus kepada agenda untuk pertumbuhan ekonomi Negara dan masyarakat tetap harus memenuhi kebutuhan sehari-hari sehingga menyebabkan penerapan PSBB ini terkadang diabaikan oleh masyarakat (Sidik et al., 2020). Berdasarkan konsep implementasi kebijakan, monitoring yang terbatas disebabkan oleh koordinasi yang lemah antara pengambil keputusan. Dalam masalah Covid-19 saat ini, Prof. Dr. Erwan Agus Purwanto berpandangan adanya ego sektoral dalam kabinet yang baru dibentuk 100 hari. Sikap dari kabinet baru masih berusaha untuk mencapai dan menjaga prestasi masing-masing, khususnya berkaitan dengan pertumbuhan ekonomi. Selain itu, rivalisasi dalam politik pasca pemilu 2019 masih berlangsung hingga kini membuat koordinasi dalam kebijakan untuk penanganan Covid-19 semakin terkendala.

Pemerintah Kota Tarakan, Kalimantan Utara memberlakukan sejumlah aturan baru setelah usulan pembatasan sosial berskala besar (PSBB) diterima Kementerian Kesehatan yang tertuang didalam peraturan walikota Kota Tarakan Nomor 17 Tahun 2020 Tentang Pelaksanaan Pembatasan Sosial Berskala Besar Dalam Rangka Percepatan Penanganan Corona Virus Disease 2019 Covid-19 Di Kota Tarakan. UU No 17 Tahun 2020 Dalam Pasal 4 Ruang lingkup peraturan walikota ini meliputi :

a. Pelaksanaan PSBB

b. Hak, Kewajiban, serta pemenuhan kebutuhan dasar selama PSBB

c. Sumber daya penanganan selama COVID-19

d. Pemantauan, evaluasi, dan pelaporan

e. Sanksi

Sumber daya penanganan selama Covid-19 Melakukan Pendistribusian Bantuan di provinsi Kaltara disalurkan secara berkala, Tiap daerah mendapatkan bantuan APD (alat pelindung diri) dari Pusat melalui Gugus Tugas. APD telah didistribusikan ke rumahrumah sakit rujukan, juga ke Dinas Kesehatan kabupaten/kota. Pemrov Kaltara juga memastikan ketersediaan sembako dan stabilitas harganya harus aman. Melalui sumbangan gubernur dan pemasukan 3.877 aparatur sipil negara Pemprov Kaltara. Dalam hal ini bantuan yang diberikan berupa uang tunai yang kemudian akan di alokasikan kepada masyarakat terkena dampak. Bantuan ini diharapkan mampu menjadi solusi bagi masyarakat tang terkena dampak terkhusus bagi masyarakat yang perekonomiannya tidak stabil. Nilainya sekitar Rp 2 miliar, yang dibagi untuk 10.000 
warga. di mana per KK menerima Rp 200.000. Berikut Grafik kasus terkonfirmasi dalam 1 hari per tanggal 04 Januari 2021:

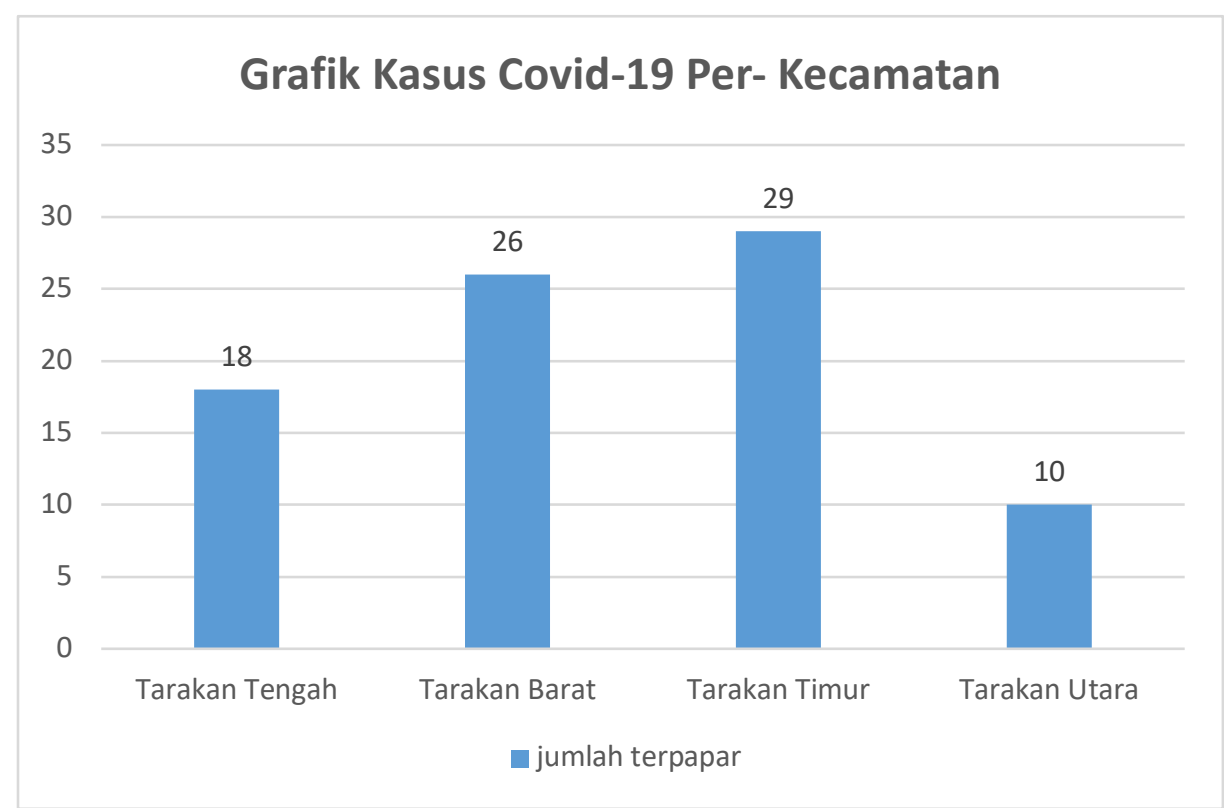

Gambar 2. Grafik Kasus Covid 19 Per-Kecamatan Sumber: Data BPBD Kota Tarakan

\section{a. Pembatasan Sosial Berskala Besar}

Setelah dilakukan kajian tentang landasan kesehatan masyarakat, dan membentuk keputusan kebijakan dan praktik berbasis bukti dengan mengidentifikasi faktor risiko penyakit, dan pertimbangan kesiapan daerah, kota Tarakan diberi izin Menkes Terawan untuk melakukan PSBB. Pelaksanaan PSBB di Kota Tarakan telah dilaksanakan, namun tidak terlepas dari beberapa permasalahan yang di alami masyarakat mulai dari bantuan yang tidak merata, aturan yang tumpang tindih, sanksi yang tidak jelas bagi pelanggar kebijakan sampai larangan rutinitas keagamaan memunculkan permasalahan sendiri bagi pemerintah Kota Tarakan. Pemerintah diminta sedia dari sekarang dalam menjamin masyarakat selama pembatasan-pembatasan berlaku. Yang harus diperhatikan adalah disiplin masyarakat dalam menjalankan protokol. Permasalahan selanjutnya adalah pemerintah menghimbau agar menutup fasilitas umum dan sekolahsekolah yang harus menggunakan sistem pembelajaran menjadi daring/online. Penerapan Sistem Belajar dari Rumah dan WFH (Work From Home). Pemprov melalui Gubernur mengeluarkan kebijakan, sebagai turunan kebijakan pemerintah (pusat), yakni menerapkan kegiatan belajar dari rumah dengan sistem online bagi siswa SMA/SMK/SLB mulai 20 Maret. Juga penerapan kebijakan bekerja dari rumah bagi para pegawai. Hal ini menjadi beban tersendiri untuk orang tua yang harus meluangkan waktu untuk mendampingi anaknya bersekolah dari rumah terutama di jenjang TK dan SD. Selain orangtua siswa, tenaga pengajar bahkan mahasiswa. Kendala yang terjadi 
seperti jaringan yang tidak stabil menjadi penghambat untuk mahasiswa mengakses info-info yang disampaikan oleh dosen melalui online.

\section{b. Evaluasi dan Pemantauan}

Pemerintah kota Tarakan sejauh ini telah melakukan evaluasi efektivitas penerapan sejumlah aturan baru selama PSBB, Pelanggaran yang terbanyak ditemukan adalah pada jalan masuk jalur laut di Pelabuhan Tengkayu Tarakan. Pelabuhan Tengkayu yang merupakan akses laut dari beberapa kota yang ada di provinsi Kalimantan Utara, masih ada speedboat yang membawa penumpang masuk wilayah Kota Tarakan pada malam hari dengan maksud agar tak terpantau petugas. Walaupun pemerintah Kota Tarakan telah menutup semua akses laut dilarang namun tetap saja beberapa speed dari beberapa daerah masih membawa penumpang selama PSBB. Pemerintah Kota Tarakan, Kalimantan Utara (Kaltara) melakukan pengawasan terhadap sejumlah akses keluar masuk seiring pemberlakukan Pembatasan Sosial Berskala Besar (PSBB).

Pemerintah Kota Tarakan menghimbau agar sejumlah pintu masuk pelabuhan dilakukan pengawasan ketat baik itu akses pada pelabuhan kapal pelni maupun jalur pelabuhan kapal feri agar dapat membatasi dan mengurangi jumlah pergerakan masyarakat antar wilayah. Sehingga, jalur untuk masuk pelabuhan diperketat dan dilakukan pengawasan dan pengawalan oleh petugas pelabuhan. Meski demikian, masih ada saja sejumlah oknum Aparatur Sipil Negara (ASN) di lingkungan Pemprov Kaltara dan anggota dewan masuk ke Tarakan melalui jalur tikus. ASN dari berbagai provinsi termasuk juga anggota dewan masih banyak yang mondar mandir menggunakan jalur tikus dari Tanjung Selor (Ibu Kota Kaltara). Di kawasan bibir pantai dengan pemukiman padat yang menjadi jalur tikus untuk pergerakan orang-orang keluar masuk Kota Tarakan. Secara geografis, letak Tarakan dan Ibu Kota Kaltara, Tanjung Selor bisa dilalui menggunakan Speedboat. Biasanya pergerakan orang-orang antardua wilayah ini rutin sebelum ada pandemi.

Selain jalur laut, Pemerintah Kota Tarakan juga menghimbau masyarakat untuk menerapkan 3M yaitu menggunakan masker, mencuci tangan, menghindari kerumunan. Namun penggunaan masker diluar rumah belum sepenuhnya dipatuhi masyarakat. Setiap harinya ditemukan setidaknya 40 orang dalam sehari yang tidak menggunakan masker saat keluar rumah. Selain itu, terdapat pelanggaran jam buka tutup toko baik itu toko sembako maupun cafe ataupun rumah makan yang dikunjungi masyarakat Kota Tarakan. Butuh komunikasi yang baik dengan berbagai pihak, khususnya Pemprov dan Pemerintah Kota Tarakan kepada masyarakat yang masih tidak taat aturan. Perlu pencermatan dalam pengawasan ketat, terhadap kebijakan 3M ini. Pemkot Tarakan juga mengeluarkan aturan untuk sanksi bagi yang tidak mematuhi aturan, pelanggar akan dikenakan Sanksi berupa denda hingga Penjara. Namun sanksi ini belum berdampak dan mendapat pengaruh pada masyarakat untuk mematuhi aturan karena masih banyaknya ditemukan pelanggaran-pelanggaran yang dilakukan. 
Penerapan Pembatasan Sosial Berskala Besar (PSBB) di Tarakan juga menjadi salah satu hambatan pengiriman sampel swab dari Kabupaten Nunukan. Dikarenakan seluruh akses transportasi di Kota Tarakan dihentikan. Pengiriman sampel swab dari Nunukan melalui Bandara Juwata Tarakan untuk diterbangkan ke Surabaya. Selain letak Kabupaten Nunukan yang menjadi kendala keterlambatan swab, pemberlakuan PSBB di Kota Tarakan juga menjadi hambatan. Pengiriman sampel swab menjadi tugas Gugus Tugas Provinsi Kaltara untuk mencarikan solusi. Pengiriman Swab harus melakukan koordinasi terlebih dahulu dengan kantor Kesehatan Pelabukan Tarakan untuk menjadwalkan schedule pengiriman dengan menggunakan jalur pesawat. Ketika schedule telah terkonfirmasi dan sudah ada jadwal, maka tim dari provinsi mendatangi Kabupaten Nunukan mengambil swab dan kembali ke Tarakan.

\section{Kesimpulan}

Dari hasil pembahasan diatas dapat dapat disimpulkan, Kota Tarakan sebagai kota transit antar beberapa daerah yang ada di Kalimantan Utara menjadikan titik fokus pemerintah dalam penanganan penyebaran kasus Covid-19. Pemerintah Kota Tarakan, Kalimantan Utara memberlakukan aturan baru setelah usulan pembatasan sosial berskala besar (PSBB) diterima Kementerian Kesehatan yang tertuang didalam peraturan walikota Kota Tarakan Nomor 17 Tahun 2020 Tentang Pelaksanaan Pembatasan Sosial Berskala Besar Dalam Rangka Percepatan Penanganan Corona Virus Disease 2019 Covid-19 Di Kota Tarakan. Selama Pelaksanaan PSBB Pemerintah Kota Tarakan telah melakukan evaluasi di masyarakat dan ditemukan beberapa aturan yang dikeluarkan belum berjalan dengan tertib salah satunya yang paling banyak ditemukan pelanggaran pada akses laut (baik itu masyarakat, ASN, bahkan Legislator Daerah). Penerapan 3M juga belum berjalan dengan efektif karena masih banyaknya masyarakat yang kurang kesadaran untuk menggunakan masker pada saat diluar rumah. Berbagai dinamika yang terjadi, Pemkot Tarakan sebisa mungkin mencari solusi yang tanggap terhadap permasalahan seperti yang terjadi pada pengiriman swab dari Kabupaten Nunukan ke Surabaya yang harus melalui Kota Tarakan. 


\section{Daftar Pustaka}

Agustino, L. (2008). Dasar-Dasar Kebijakan Publik. Bandung : Alfabeta.

Dian Herdiana. (2018). Sosialisasi Kebijakan Publik: Pengertian dan Konsep Dasar. Jurnal Ilmiah Wawasan Insan Akademik, 1(3), 13-26.

Dutta, P. (2020). Democratic Decentralization and Participatory Development: Focus on Bangladesh. Journal of Contemporary Governance and Public Policy, 1(2), 82-91. https://doi.org/10.46507/jcgpp.v1i2.23

Islamy, M. I. (2009). Prinsip-Prinsip Perumusan Kebijaksanaan Negara. Jakarta:Bumi Aksara.

Johnston, M. P. (2014). Secondary Data Analysis: A Method that which a Time Has Come. Quantitative and Qualitative Methods in Library. QQML.

Moleong. (2010). Metodologi Penelitian Kualitatif. Bandung: PT. Remaja Rosdakarya.

Mustari, N. (2015). Pemahaman Kebijakan Publik; Formulasi, Implementasi, Evaluasi. LeutikaPrio.

Ramdhani, A., \& Ramdhani, M. A. (2017). Konsep Umum Pelaksanaan Kebijakan Publik. Jurnal Publik, 1-12. https://doi.org/10.1109/ICMENS.2005.96

Ristyawati, A. (2020). Efektifitas Kebijakan Pembatasan Sosial Berskala Besar Dalam Masa Pandemi Corona Virus 2019 oleh Pemerintah Sesuai Amanat UUD NRI Tahun 1945. Administrative Law and Governance Journal, 3(2), 240-249. https://doi.org/10.14710/alj.v3i2.240-249

Saraswati, P. S. (2020). Kebijakan Hukum Terhadap Penanganan Pandemi Covid-19 di Indonesia. Kertha Wicaksana, 14(2), 147-152. https://doi.org/10.22225/kw.14.2.1923.147-152

Sidik, S., Hasrin, A., \& Fathimah, S. (2020). Analisis Dampak Kebijakan Pembatasan Waktu Operasional Pasar Di Kabupaten Minahasa Akibat Penanggulangan Covid-19. JISIP (Jurnal Ilmu Sosial Dan Pendidikan), 4(3). https://doi.org/10.36312/jisip.v4i3.1160

Tahir, M. M., \& Harakan, A. (2017). Inovasi Program Kesehatan 24 Jam Dalam Mewujudkan Good Health Care Governance di Kabupaten Bantaeng. Jurnal Ilmiah Muqoddimah, 2, 13-22.

\section{Referensi Media}

Muhartini, Tri. 2020.Reportase Dinamika Kebijakan Krisis COVID-19 (Laporan dari FISIPOL). diambil dari https://kebijakankesehatanindonesia.net/4074-reportasedinamika-kebijakan-krisis-covid-19-laporan-dari-fisipol (diakses junuari 2021)

Daton, Zakarias Demon. 2020. Evaluasi 15 Hari PSBB Tarakan, Pelanggaran Terbanyak di Pelabuhan diambil dari https://regional.kompas.com/read/2020/05/10/07564041/evaluasi-15-haripsbb-tarakan-pelanggaran-terbanyak-di-pelabuhan. (diakses pada januari 2021)

Adityo, Mansur. 2020. Tarakan Mulai Uji Coba PSBB, Ini Aturan-aturannya. Diambil dari https://selasar.co/read/2020/04/22/1452/tarakan-mulai-uji-coba-psbb-besokini-aturan-aturannya. (diakses pada Januari 2021).

Mashabi, Sania. 2020. Menkes Setujui PSBB Kota Tarakan dan Banjarmasin. Diambil dari https://nasional.kompas.com/read/2020/04/20/12225191/menkes-setujuipsbb-kota-tarakan-dan-banjarmasin?page=2. (diakses pada Januari 2021) 


\section{Peraturan Perundang-undangan}

Perwali Nomor 17 Tahun 2020 Tentang Pelaksanaan Pembatasan Sosial Berskala Besar Dalam Rangka Percepatan Penanganan Corona Virus Disease 2019 Covid-19 Di Kota Tarakan.

PP Nomor 21 Tahun 2020 Tentang Pembatasan Sosial Berskala Besar dalam Rangka Percepatan Penanganan Corona Virus Disease 2019 (COVID-19) 